\title{
The theological paraphrasing of history: The Exodus tradition in the Wisdom of Solomon
}

\begin{abstract}
Author:
Hendrik L. Bosman ${ }^{1}$

Affiliation:

${ }^{1}$ Department of Old and

New Testament, Stellenbosch

University, South Africa

Correspondence to:

Hendrik Bosman

Email:

hlb1@sun.ac.za

Postal addresss:

Private Bag X1, Matieland

7602 , South Africa

Dates:

Received: 05 Sept. 2012

Accepted: 02 Oct. 2012

Published: 28 Nov. 2012

How to cite this article:

Bosman, H.L., 2012, 'The

theological paraphrasing of

history: The Exodus tradition

in the Wisdom of Solomon',

HTS Teologiese Studies/

Theological Studies 68(1),

Art. \#1329, 7 pages. http://

dx.doi.org/10.4102/hts.

v68i1.1329
\end{abstract}

(C) 2012. The Authors.

Licensee: AOSIS

OpenJournals. This work

is licensed under the

Creative Commons

Attribution License.
This study of the reinterpretation of the exodus tradition in the Wisdom of Solomon investigated the possibility that the reinterpretation entailed the alignment of history and wisdom. To come to grips with this alignment, attention had to be paid to its Greco-Roman context, whilst also taking into consideration the literary and theological structure of the Wisdom of Solomon, as well as its rhetoric and genre. In a theologically creative manner, Wisdom (as divine personification) and history (as memories of salvation during the Exodus) were combined in the Wisdom of Solomon to convince the Jews in the diaspora that justice would prevail - not only in this life but also thereafter. By means of poetic imagery, rhetorical skill, historical reinterpretation and imaginative wisdom theology, religious identity were not only bolstered to resist a dominant Greco-Roman culture but also to develop a positive view of creation according to the values of wisdom exemplified by the reinterpreted Exodus traditions.

\section{Introduction}

The relationship between Israelite and early Jewish wisdom, history and theology has been a perennial bone of contention in biblical studies for the past century. Biblical scholarship has often presumed a direct equivalence between salvation history and theology and the absence of the former caused many a scholar to assume the absence of the latter. Although Proverbs, Job and Ecclesiastes are not renowned for their attention to any obvious forms of salvation history, their particular mode of (non-historical?) theology was only appreciated during the last few decades.

This contribution is focused on the possible theological reinterpretation of Israelite history in the second half of the Wisdom of Solomon where numerous aspects of the exodus tradition were paraphrased to address the context of the Jewish community in the 1st century diaspora (Alexandria?). ${ }^{1}$ The remarkable blending of Greco-Roman philosophy and rhetoric with Jewish scripture and theological tradition forms a fascinating multicultural backdrop for the appropriation of the exodus tradition. ${ }^{2}$

It must be made quite clear that there are numerous references to the exodus outside of the Hebrew Bible or Old Testament, but that the Wisdom of Solomon is focused on, due to its significant synthesis of Jewish and Greco-Roman cultures illustrated by its reinterpretation of events during the exodus. ${ }^{3}$ Nickelsburg (2000:152) described this cultural synthesis as the wedding of 'Jewish apocalyptic tradition about judgment and heavenly exaltation with Greek philosophy and literary and rhetorical forms'.

This study of the reinterpretation of the exodus tradition in the Wisdom of Solomon investigates the possibility that the reinterpretation entailed the alignment of history and wisdom. ${ }^{4}$ To come to grips with this alignment attention must be paid to its Greco-Roman context, whilst also taking into regard the literary and theological structure of the Wisdom of Solomon, as well as its rhetoric and genre.

1.Not all scholars agree that the Wisdom of Solomon or Book of Wisdom constitutes a rewriting or reinterpretation of the story of Exodus. Zsengeller (2010:197) argues that 'the Book of Wisdom does not really rewrite the previous narratives, neither interprets them but uses them as a source of reference.' One could respond by reflecting on whether the way in which a text is referenced also amounts to a form of (re)interpretation?

2.Kolarcik (2009:330) points out that the Wisdom of Solomon displays a familiarity both with 'Greek rhetoric and with Platonic and Stoic philosophical discourse', as well as biblical traditions such as 'Genesis, Exodus, Davidic kingship, Isaiah, and the sapiential texts of Proverbs and Sirach.'

3. References to the exodus can be found in the Apocrypha: Baruch 1:18ff.; 2:11; 28; Judith 5:12ff.; 6:5; I Maccabees 4:9; II Maccabees 2:4, 8, 10f.; Sirach 45; 46:7ff.; in the Pseudepigrapha: Assumption of Moses 1:4ff.; 3:11ff.; 11:1ff.; 12:1ff.; II Baruch (Syriac not Greek)

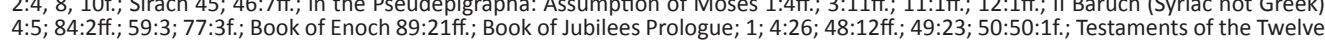
4:5; 84:2ff.; $59: 3$; 77:3f.; Book of Enoch
Patriarchs: Simeon 9:2; Benjamin 12:4.

4.One could also ask why this contribution focuses on the Exodus tradition? One is then well reminded to take note of Gruen's (1998:41) statement about the ongoing importance of the Exodus: 'The Exodus was a defining moment, perhaps the defining moment in ancient Israelite tradition.' 


\section{Greco-Roman context of the Wisdom of Solomon}

The Wisdom of Solomon was probably composed in Greek during the early Roman period (1st century CE) and the unknown author is presumed to have resided in Alexandria, Egypt (Weeks 2010:95). ${ }^{5}$ In his influential Anchor Bible commentary David Winston (1979:20-25) has argued that the writing of the Wisdom of Solomon can be related more specifically to anti-Jewish persecution in Alexandria during the rule of the Roman emperor Gaius Caligula (37-41 CE). ${ }^{6}$ The link with a Hellenistic environment is generally accepted but the more specific connection with the uprising against Caligula is based on rather slim evidence. To mention only one example: the rage expressed in Chapter 5 was supposed to be triggered by a 'desperate historical situation' - without a shred of evidence that it alluded to Caligula. ${ }^{7}$

A few examples of Jewish writings will be discussed that came to light during the Greco-Roman period that might be considered when one attempts to make sense of the Exodus tradition in the Wisdom of Solomon ${ }^{8}$ :

1. The Jewish historian, Artapanus, wrote Judaica and Concerning the Jews in c. 200 BCE in Egypt. He combines encomium [praise] with apologia [defence] when he praises three heroes of Jewish history by describing how they contributed to Egyptian culture: Abraham is credited with teaching the Egyptians astrology; Joseph is portrayed as the 'lord of Egypt' who instituted important cultural advances; Moses is depicted as the inventor of ships and equipment as well as being a military strategist of note (Perdue 2008:298-299).

2. Ezekiel the Tragedian, was also a Hellenistic Jew of the 2nd century BCE who wrote a tragedy entitled Exagoge ['Leading out']. In this tragedy Moses is glorified and the exodus is described as 'an event under the direction of God' that resembles the third section of the Wisdom of Solomon (Perdue 2008:300).

3. Philo Judaeus (c. 15-50 BCE) is the best-known Jewish author who combined Hellenistic culture and philosophy with a thorough knowledge of Jewish religion. His numerous writings show clear influence from Platonism and some influence of mysticism and Pythagorean

5.The book under discussion was known by different titles: the most common title used is derived from the Septuagint ('Wisdom of Solomon'), whilst the Vulgate referred to it as 'the Book of Wisdom' (still used by Roman Catholic authors).

6.Collins (2005a:181) investigated whether the 38 CE riots in Alexandria can be understood as an example of anti-Semitism in antiquity and came to the conclusion that the 'Jews of Alexandria were no more different from their neighbours than the that the Jews of Alexandria were no more different from their neighbours than the Jews of Asia Minor ... To speak of anti-Semitism as if it were some kind of ahistorical
virus is only the obverse of the genuinely, anti-Semitic tendency to find the cause of conflict in the Jewish, or Semitic, character' (Collins 2005a:201).

7.Wiles (2002:35-36) accepts the undeniable Hellenistic influence with regard to rhetoric and philosophy, but considers it 'less convincing' to pinpoint the uprising against Caligula as being 'the likeliest setting' of the book. Even a wisdom expert like Roland Murphy (2000:115) is extremely cautious about the time and location of the Wisdom of Solomon: 'The author was an erudite Jew of the diaspora, probably living in Alexandria ... It is very difficult to fix a date, but sometime around the beginning of the first century BCE or CE seems likely.'

8.Brief mention can also be made of Greco-Egyptian authors like Manetho, 8.Brief mention can also be made of Greco-Egyptian authors like Manetho, of Egypt due to leprosy and related diseases. Since there is no clear evidence that the exodus tradition was known or accessible to these authors, little attention for the exodus tradition was known or accessible to these authors, little attention for
these writers is warranted due to the focus on the reinterpretation of elements in these writers is warranted due to the foc
the Book of Exodus (Gruen 1998:70-71). numerology. ${ }^{9}$ It is instructive to note that Philo was full of praise for the piety and virtue of Jewish religion (encomium) which was contrasted with the 'irrational, carnal character of the Egyptians, who are yoked to the body and its passions' (Perdue 2008:304). Similar to the Wisdom of Solomon the plagues are described as the way in which the wrath of God was vented against the Egyptians. ${ }^{10}$

Within the Greco-Roman environment of the diaspora, the Jews had to negotiate their daily existence between two alternatives: 'the desire to survive and thrive' in a Gentile world as well as 'the desire to remain faithful to and preserve their Jewish heritage and identity' (DeSilva 2002:60). There are at least three basic ways in which the Jews responded to their context in the diaspora (Barclay 1996:92-101): assimilation (becoming integrated into the dominant culture and abandoning markers of their own identity); acculturation (the internalisation of the dominant culture that entails appropriating elements of language, values and traditions) and accommodation (conforming to the dominant GrecoRoman culture and maintaining their own unique cultural identity and traditions). ${ }^{11}$

\section{Structure, rhetoric and genre of the Wisdom of Solomon}

Winston (1979:14-18) provides a detailed argument that the author of the Wisdom of Solomon was proficient in both stylish Hebrew (frequent use of parallelismus membrorum etc.) and eloquent Greek literary style (making use of iambic or hexameter rhythm in 10:9; 14:26; 15:4; 18:4 and stylistic devices such as anaphora in ch. 10 where repetition is found at the beginning of successive lines; chiasmus in 1:1; 3:15 etc.; 240 examples of hyperbaton especially in the last nine chapters where there are numerous departures from standard syntax for the sake of emphasis or poetic effect; litotes 1:2; 19:22 etc. when an affirmative is expressed by negating its opposite).

Scholarly debate on the structure of the Wisdom of Solomon took note of changes in form and content in the book as a whole. Chapters 1-9 constitute a more proverbial type of wisdom literature with a thematic focus on immortality; whilst Chapters 10-19 consist of retrospective historical-like narratives often referring to elements of the exodus tradition and focusing on idolatry (Enns 2008:886). The Wisdom of Solomon is usually divided in two or three parts. Addison Wright (1967:165-184) counted all the stichoi and established that Chapters 1:1-11:1 and 11:2-19:22 have almost the same number (560 and 561 stichoi respectively). Winston (1979:4) is one of several commentators who prefer a threefold division:

9.According to Perdue (2008:303) Philo was influenced by the Greek paideia whose curriculum consisted of philosophy, grammar, geometry and music. Philosophy consisted of logic, ethics and physics (esp. cosmology).

10.Some scholars have suggested that Philo was the author of most of the book the Wisdom of Solomon.

11.Gruen (1998:72) argues how the Jews in the diaspora adapted the Exodus traditions 'to elevate their own part in the history of their adopted land.' 
- Wisdom's Gift of Immortality (1:1-6:21). ${ }^{12}$

- The Nature and Power of Wisdom and Solomon's Quest for Her (6:22-10:21)..$^{13}$

- Divine Wisdom of Justice in the Exodus (11-19). ${ }^{14}$

- Excursus 1: Divine Mercy (11:15-12:22).

- Excursus 2: On Idolatry (13-15).

The Wisdom of Solomon is in several ways 'a different kind of book from the older wisdom writings of Proverbs, Qoheleth and Ben Sira' (Collins 2005c:143). In his commentary Focke (1913:86) suggested that in general the genre of the Wisdom of Solomon can best be described as an 'exhortatory discourse' (logos protreptikos) that urges people to say or do something. ${ }^{15}$ This suggestion that the Wisdom of Solomon is a 'didactic exhortation' has more recently been affirmed by scholars like Reese (1970:119-121) and Winston (1979:18). A different suggestion about the genre is made by Gilbert (1984:307-308) who interprets the Wisdom of Solomon as speech in which Wisdom is praised by means of an encomium, or as DeSilva (2002:134) puts it: 'an example of epideictic or demonstrative oratory, a work the goal of which is to win the assent of the hearers to a particular set of values.' Due to the rhetorical diversity in the book a single genre cannot do justice to the whole that incorporates both exhortative as well as demonstrative strategies of persuasion. In Chapters 1-6 the hortatory rhetoric is paramount whilst in Chapters 7-19 the epideictic oratory dominates (DeSilva 2002:134-135).

If one pays more attention to the second half of the book one should take note of the comment made by Murphy (2000:115) that the references in the Wisdom of Solomon to 'the Egyptian plagues' resemble a 'kind of midrash'. These midrashic references to elements of the exodus tradition can be interpreted within the context of the 'workings of wisdom in history' in Chapters 10-19 'where the success of the heroes of biblical history is attributed to the guidance of wisdom, beginning with Adam, whom she delivered from his transgression' (Collins 2005c:144). ${ }^{16}$

Not all scholars agree that the biblical interpretation found in the Wisdom of Solomon is similar to the midrash, targum and pesher found in the Palestinian interpretation of Scripture. Cheon (1997:150-151) concludes that 'Pseudo-Solomon' reshapes the biblical story by being 'not fully attentive to

12. Horbury (2000:650) describes how the first section of the Wisdom of Solomon begins with 'instruction to kings on wisdom, as regards the suffering and vindication of the righteous' and 'the doctrine of immortality is presented as the confirmation first section as an 'Exhortation to justice'.

13. Horbury (2000:650) points out in the second section 'King Solomon emerges by implication as the speaker, telling the Gentile kings how he prayed when young for the heavenly gift of wisdom, as is related in 1 Kings 3 and 2 Chronicles 1.' Kolarcik (2009:331) provides an elaborate description of how Solomon desires wisdom in (2009:331) provides an elaborate description of how Solomon desires wisdom in
Chapters 7 and 9 and prays for wisdom in Chapter 9 . This is achieved by means Chapters 7 and 9 and prays for wisdom in Chapter 9 . This is achieved by means
of two concentric literary structures with as central message in the first circle the eulogy of wisdom consisting of 21 attributes of wisdom in 7:22b-8:1; whilst the central thrust of the second circle is found in the prayer to God to send wisdom in $9: 10 a b$. Chapter 10 will be discussed in more detail in the next section.

14.The third section will be discussed in more detail in this contribution.

15.The suggestion for a 1st-century CE setting for the Wisdom of Solomon was also advanced by Goodrick (1913) during the same year as Focke. Winston (1979:18) explains that the 'protreptic was a union of philosophy and rhetoric and originated with the Sophists...

16.Collins (2005c:144) also makes the important observation that 'Ben Sira had taken the revolutionary step of using examples from Israelite history to illustrate the workings of wisdom' - compare the description of the High Priest Simon (50:1-21) that forms the conclusion of the 'Hymn in Honor of Our Ancestors' (44:1-50:24). the biblical text', by ignoring 'the historical elements in the Bible', by not using 'any proper names from the biblical accounts', thus interpreting the biblical text 'in a positive way, combining, contrasting and exaggerating narratives of the Exodus.'

\section{Aligning Wisdom with history by means of the 'exodus tradition'}

At first a few thoughts on the concept 'exodus tradition' before it is discussed within the context of the Wisdom of Solomon. ${ }^{17}$ The exodus theme can be found in two major clusters in the Hebrew Bible or Old Testament:

1. allusions to a 15th or 13th century exodus can be found in the Book Exodus as well as a few pre-exilic psalms and prophetic tests

2. the 6th century return from exile in Babylonia that was interpreted by Deutero-Isaiah (chs. 40-55), Jeremiah and Ezekiel as a new exodus. ${ }^{18}$

There are several allusions to the exodus in the Book of Wisdom, more in the second half than in the first half - in the first half there are a few incidental allusions whilst in the second half there are much more extensive references to the exodus (Stuart 1973:36-43):

- 5:7 'We took our fill of the paths of lawlessness and destruction, and we journeyed through trackless deserts ...'

- 5:22 'the water of the sea will rage against them; and rivers will relentlessly overwhelm them ...'

- 9:8 'You have given command to build a temple on your holy mountain ... a copy of the holy tent that you prepared from the beginning.'

The most extensive existing research on the exodus tradition in the Wisdom of Solomon is by Samuel Cheon (1997) who examined the biblical interpretation found in the Wisdom of Solomon 11:1-14 and 16:1-19:22 that are related to aspects of the exodus. His evaluation of this biblical interpretation boils down to an argument for the reshaping of the story and not a midrash - and this 'reshaping' entails the free use of intertextual material, producing a creative composition informed by Jewish faith and Hellenistic philosophy. The audience of the book seems to be well acquainted with the biblical exodus story - Jews in the diaspora? It seems likely that the author of the book had an apologetic intention to preserve Jewish identity and at the same time counteract the anti-Semitic literature of the Gentiles (Cheon 1997:149).

Cheon (1997:145-147) agrees with Blenkinsopp's (1981:1-20) conclusions about Jewish self-definition in the Second Temple

17.For the purpose of this article I concur with Stuart (1973:15) that the exodus tradition entails 'those traditions concerning the deliverance of Israel from Egypt until the entrance into the Promised Land.' Daube (1963:11) starts his discussion of the exodus pattern by assuming that 'the narrative of the exodus inspires those who recount the disasters and salvations of Israel, ancient or modern, secular or spiritual' and he also refers to the exodus 'as a prototype, as a mould in which other stories of rescue from ruin can be cast.

18.Clifford (2002:345) also refers to a third cluster within the Christian Bible 'the work of Jesus in the first century CE, interpreted by the New Testament writers as a new Exodus'. This might be of some interest for the Wisdom of Solomon because it most probly it most probably originated within the same period of time. It is surprising that an Important theme in Supper (1 Cor 10) (ii) as model for salvation actualized in baptism and the Lord's Supper (1 Cor 10); (ii) as motive for encouragement during the end time (Rv 12) and as a paranetic warning for Christians in view of the failure of Israel in the desert (1 Cor 10; Heb 3; Jude 5).' 
Period: 'the interpretation or reinterpretation of tradition expressed in texts determined the self-understanding and self-definition of Judaism in Palestine.' This conclusion also resonates with the research by Stone (1980:88-89) on the use of Scripture by Jews in Alexandria who also 'took the biblical record and sought in it events and facts which would give a legitimation of their own position in Egypt.'

Subsequently Lietaert Peerbolte (2006) is critical of Cheon's study with regards to the presumed link between the Wisdom of Solomon and the riot (pogrom?) during the reign of Caligula:

The main problem here is the danger of circular reasoning: the literary picture of the Egyptians as oppressors in the Book of Wisdom is extrapolated into a historical situation of oppression. It is this situation of oppression that is subsequently taken as the context in which the writing originated. In search of any such possible context the identification with the Alexandrian crisis under Gaius is made. (p. 98)

Lietaert Peerbolte (2006) considers it important:

to see that the account of Exodus given in the Book of Wisdom has been influenced in a diachronic manner by the tradition in which it stands and in a synchronic manner by the specific circumstances under which it was written. (p. 115)

He makes an interesting argument for the socio-rhetorical function of the rewriting of the exodus narrative: 'the warnings against idolatry are not primarily against the oppressive Egyptians, but are meant to close the boundaries between Jews and Gentiles.'

The figure of Wisdom is chosen by the Wisdom of Solomon to act as mediator (mediatrix) of the theological message to its audience in Alexandria. Wisdom bridges the divide, separating the gap between the 'exclusive nationalist tradition of Israel and the universalist philosophical tradition' prevalent in Greco-Roman Alexandria (Winston 1979:37). The blending of different cultures becomes even more striking when one realises that there is a striking resemblance between the way Sophia is portrayed in the Wisdom of Solomon and the aretalogies of the Egyptian goddess Isis (Reese 1970:36-50).

Chapter 10:1-21 acts as a bridging passage between the previous sections and the last section providing 'a detailed recitation of Wisdom's saving power in history from Adam through Moses and the Exodus' (Winston 1979:6). In an informative analysis of the bridging chapter Kolarcik (2009:332) establishes how the skilful rhetorician used seven brief diptychs to express how Wisdom came to the aid of the righteous and how the unrighteous got bogged down in failure - although the description makes it quite clear who is being referred to, not a single personal name is mentioned and anonymity is maintained:

- 10:1-3 Adam is contrasted with Cain. ${ }^{19}$

- 10:4 Noah is contrasted with those who succumbed to the Flood. ${ }^{20}$

19.According to $10: 1-3$ it is Wisdom who protected Adam as the 'first-formed fathe of the world' and who 'gave him strength to rule all things', whilst Cain is referred to as 'an unrighteous man' who perished 'because in rage he killed his brother.'

20.10:4 'When the earth was flooded because of him (= Cain or unrighteous humankind), Wisdom again saved it, steering the righteous man (= Noah) by a paltry piece of wood.'
- 10:5 Abraham is juxtaposed to the nations of Babel. ${ }^{21}$

- 10:6-8 Lot is contrasted with the inhabitants who perished in the cities on the plain and his wife. ${ }^{22}$

- 10:9-12 Jacob is juxtaposed with Esau and his personal opponents. ${ }^{23}$

- 10:13-14 Joseph is contrasted with his brothers and Potiphar's wife. ${ }^{24}$

- 10:15-21 Moses and the Israelites are contrasted with the Egyptians, their oppressors. ${ }^{25}$

In Chapters 11-19 the author of the Wisdom of Solomon formulated an elaborate comparison (synkrisis) by means of a series of antitheses that will be discussed in more detail (Winston 1979:6). This third section of the book starts with an introductory narrative in 11:1-4 that immediately emphasises the importance of Wisdom and Moses: 'Wisdom prospered their works by the hand of a holy prophet.' The exodus is summarised by highlighting the following elements that illustrate the favourable impact of Wisdom in the history of Israel:

1. the wandering through the 'uninhabited wilderness' (11:2).

2. the enmity with regards to enemies and foes along the way (11:3).

3. the provision of water 'out of a flinty rock' when they were thirsty (11:4).

The main point of the extensive comparison (synkrisis) and the theme for the subsequent rewriting of the exodus is provided in 11:5 - 'For through the very things by which their enemies were punished, they themselves received benefit in their need.' The doctrine of retribution ('an eye for an eye') is here given an ironic twist by explaining the ambivalence of the so-called plagues or signs in Egypt: what was punishment for their enemies was beneficial for Israel in need. Perdue (2007: 311) points out that a variation of this central theme is provided in 11:16 according to which divine retribution is depicted as a process where one is punished by 'the very things by which one sins.'

The midrashic reinterpretation of the exodus narrative is formed by seven antitheses gleaned from Israel's past. In this focus on Israel's history Lady Wisdom is less obvious because God becomes the protagonist who assists 'the righteous with all the forces of creation' (Kolarcik 2009:332; Perdue 2008:328; Winston 1979: 11-12; Reese 1965:391-399):

21.10:5 'Wisdom also, when the nations in wicked agreement had been put into confusion (= at Babel?), recognised the righteous man (= Abraham) and preserved him blameless before God.'

22.10:6 'Wisdom rescued a righteous man (= Lot) when the ungodly were perishing: he escaped the fire that descended on the Five Cities (Pentapolis or Sodom, Gomorrah, Admah, Zeboiim and Zoar - Gn 10:19; 14:2?)'

23.10:9-10 'Wisdom rescued from troubles those who served her. When a righteous man (= Jacob) fled from his brother's (= Esau) wrath, she guided him on straight paths; she showed him the kingdom of God.'

24.10:13 and $14 \mathrm{~b}$ 'When a righteous man (= Jacob) was sold, Wisdom did not desert him, but delivered him from sin. She descended with him into the dungeon ... 'and 'those who accused him (= Potiphar's wife) she showed to be false.'

25.10:15-21 'A holy people and blameless race Wisdom delivered from a nation of oppressors (= Egyptians). She entered the soul of a servant of the Lord (= Moses) and withstood dread kings with wonders and signs ... She brought them over the Red Sea, and led them through deep waters; but she drowned their enemies, and Red Sea, and led them through deep waters; but she drowned their enemies, and
she cast them up from the depth of the sea. Therefore the righteous plundered the ungodly; they sang hymns, O Lord, to your holy name.' 
- 11:6-14 The Egyptians are plagued by undrinkable water due to the water of the Nile that turned into blood whilst the Israelites enjoy drinkable water from the rock in the wilderness.

- 16:1-4 The Egyptians are hungry due to the animal plague in contrast to the Israelites who enjoy quails.

- 16:5-14 Egyptians are plagued by locusts and flies, but Israel survives a snake attack through the bronze effigy of a serpent.

- 16:15-29 Egyptians are plagued by thunderstorms and hail (plague) and this is juxtaposed with Israel who is fed by the 'rain' of manna.

- 17:1-18:4 Egyptians are terrified by the plague of darkness and this is in contrast to the pillar of fire that guided Israel in the wilderness.

- 18:5-25 The 10th plague of the killing of the Egyptian first born is compared antithetically with the protection and glorification of Israel.

- 19:1-9 Whilst the Egyptians drown in the sea, the Israelites pass safely through.

In between the harsh juxtaposition of Egyptians (unrighteous) and the Israelites (righteous) there are a few sections that address separate but related topics. The first collection of 'digressions' discusses divine mercy, both towards the Egyptians (11:15-12:2) and the Canaanites (12:3-12:18) and this divine mercy is presented as a model lesson for Israel (12:19-22). According to Winston (1979:11) this first excursus is concluded by a return to the theme of measure for measure and acts as a transition to the second excursion on idolatry (13:1-15:19). It is interesting that the theme of idolatry is illustrated by the critique of nature worship (13:1-9) and wooden image-making (13:10-14:11); this is followed by a discussion of the origin and consequences of idolatry (14:1231). In contrast to idolatry a short description is provided of Israel's immunity against idolatry (15:1-6). Then the critique against idolatry continues with a description of the manufacture of clay figurines (15:7-13) and in conclusion the folly of Egyptian idolatry is argued (15:14-19). ${ }^{26}$

The last four chapters of the Wisdom of Solomon are influenced by apocalyptic thought and this can be discerned in the description of the 'transformation of the cosmos in the account of the exodus in Chapters 16-19' (Collins 2005c:145). In these four chapters the references to the exodus are used as evidence 'that justice must prevail in the cosmos' - elements of nature are changed 'so that the Israelites are sustained and their enemies are undone, so, we might think, must it also be at the end of history' (Collins 2005c:154).

The Wisdom of Solomon is a good example that early Jewish wisdom did not view the Greco-Roman context in an unhistorical manner by framing their daily experience in the diaspora with their memories about the exodus (Murphy

26.Von Rad (1972:183) and Dell (2000:138-139) claim that there is a marked difference between the polemic against idols in prophetic literature (second influence: 'There are those who see the elements as gods, when they should have recognized the Creator in what he created, and so, in that sense, they are guilty recognized the Creator in what he created, and so, in that sense, they are guilty
... It is those who worship something man-made that is lifeless who are morally $\ldots$ It is those who worship some
degenerate' (eg. Wis 13:10-19).
2002:112-113)..$^{27}$ Punishing the wicked is deferred in Jewish apocalypses 'until the eschatological period'; but in the Wisdom of Solomon 'it is an ongoing feature of cosmos and history' (Collins 2005c:157).

In the Wisdom of Solomon memories about creation and salvation are combined by illustrating these by means of examples from the exodus as to how there is a continuity between creation and salvation in the present and beyond. The historical overview from Adam to Exodus illustrates the ongoing and pervasive cosmic dimension of Wisdom that enables punishment for the wicked and blessings for the just and the righteous - not only in this life but also thereafter.

\section{Conclusion}

In the first nine chapters of the Wisdom of Solomon there is almost no clear engagement with the history of Israel, whilst there are persistent references to the memories of the past in Chapters 10-19 when personified Wisdom engages with anonymous figures and well known episodes in Israel's history (Enns 2012:391-392).

Perdue (2007) provides a good summary of the theological thrust of the Wisdom of Solomon when he points out how the author combines:

redemption history with a theology of creation: creation is not a dormant or static entity, but rather a dynamic force continually moving within an order of blessing and punishment through which God through Wisdom works to bring deliverance. ${ }^{28}$ (p. 311)

Considering all three parts of the Wisdom of Solomon, in Chapters 1-6 it is argued why it is crucial to strive for righteousness because (immortal) justice is the key virtue that provides guidance in this life and thereafter; and Chapters 7-9(10) indicate the necessity to seek divine wisdom to enable righteousness because it is only the wisdom of God that allows human beings to achieve that. Chapter 10 is a bridging passage between the second and third section that mentions figures known for their righteousness, starting with Adam and ending with Moses. Finally, Chapters (10) 11-19 describe the cosmic judgement against Egypt by means of allusions to elements of the exodus traditions and presupposing two underlying theological principles: according to 11:16 'every particular sin carries with it a correspondingly appropriate punishment' and in 11:5 and 13 it is explained 'that the very elements God employed to punish the unjust, God employed also to save the righteous' (Kolarcik 2010: 33-35).

The particularism communicated by Chapters 11-19 can be interpreted in different ways: on the one hand it seems

27. Murphy (2002:113) summarises the relation between wisdom (discerning the present) and history well: 'History is not merely the recollection of times past, but also the analysis of daily experience in which the variable and the incalculable often appear.'

28.According to Cheon (1997:151) three theological tendencies can be discerned in the Wisdom of Solomon: (1) 'On behalf of the persecuted. God retaliates against the persecutors. This retaliation contains a pedagogical intention to bring about the persecutors. This retaliation contains a pedagogical intention to bring about
the repentance of the wicked; (2) the temporal suffering of the righteous which God causes is intended to teach both them and their enemies; (3) the elements of the universe work to benefit the righteous and to punish the wicked. This understanding of creation reflects his positive perspective on present history.' To my mind Cheon provides a useful summary of the theological order presupposed by the author of the Wisdom of Solomon, but is does not do justice to the 'mysteries of God' (musteria Theou) mentioned in 2:22. 
to suggest that references to the ancient Egyptians and Canaanites in the rewriting of the exodus tradition 'merely served the author as symbols for the hated Alexandrians and Romans of his own day ...' (Winston 1979:45); but on the other hand, it is also understood as a rhetorical strategy to strengthen the boundaries between Jews and Gentiles (Lietaert Peerbolte 2006:115). One could reflect on the possibility that the premeditated anonymity of the references to the exodus could enable both resistance to anti-Semitism and the bolstering of Jewish exclusivity.

It is significant to take note of the correspondence between the Wisdom of Solomon and Hellenistic philosophy especially Stoicism - that is reflected in the emphasis on the immortality of the soul..$^{29}$ Larcher (1969:314) is of the opinion that 'immortality is both a sanction of righteousness and a favour given to the chosen', whilst Winston (1979:116) takes Wisdom of Solomon 1:15 as point of departure that righteousness and not the soul is immortal - thus immortality is grounded not in the supposed undying nature of the soul, but in righteousness as the enduring relationship with God.$^{30}$ It is important to note that in distinction to the then pervasive Platonic philosophy the soul was not considered to be inherently immortal and immortality was considered to be 'the reward for just conduct, just as eternal extinction is the consequence of wickedness' (Nickelsburg 2000:154-155).

Creative theological reinterpretation emerged when Greek philosophy was combined with Jewish spirituality. Thus the paraphrasing of the exodus was used to praise Wisdom (and God) for the guidance of 'the heroic leadership of unnamed ancestors whose deeds and virtues led to salvation' in an apologetic manner that was highly critical of Egyptian culture and religion (the combination of encomium and apologia to form a synkrisis or comparison)..$^{31}$ The anonymity of the characters in the reinterpreted exodus narrative makes its universal appeal stronger and strengthens the rhetorical strategy to convince the Jewish audience living in the GrecoRoman diaspora to open up to the guidance of Wisdom or God and maintain their religious and cultural identity in a sometimes, hostile environment.

Although one could argue that sections in the first half of the Wisdom of Solomon had a universal appeal for Jews and Gentiles, the rhetoric of especially the second half of the book is geared towards exemplifying and propagating a life style of accommodation between Greco-Roman culture and Jewish religion. Therefore the Wisdom of Solomon seems to be more orientated towards addressing members of their own culture

29.According to Green (2003:41) the 'main insight available from Wisdom of Solomon is that Wisdom, intimate of God and structuring element of all creation, saves her friends into Life, not without their collaboration, the alternative is Death.

30.The Wisdom of Solomon 1:15 is crystal clear on this point: 'For righteousness is immortal' (dikaiosune gar athanatos estin). Whilst early Jewish apocalypses like Daniel conceive afterlife as a resurrection of the dead at the end of history the apocalyptic writings in the first two centuries CE either expected a genera the righteous by means of heavenly ascent (Collins 2000:137).

31.A similar catalog of heroic figures is found in Sirach 44-50. In the Wisdom of Solomon the heroic figures are recognised by means of the historical episodes and not by means of their names, thus becoming models of virtuous conduct for all times and places (Enns 2012:397). than to provide an apology to the Gentiles on behalf of the vilified Jews (DeSilva 2002:136).

The Exodus traditions maintained a significant place in the ongoing negotiation of Jewish identity in the Greco-Roman diaspora. On the one hand, they reminded the Jews in Egypt of their longstanding association with the country, whilst on the other hand, they emphasised the profound role Wisdom played as a divine personification. Thus, the memories of the plagues as signs of the ongoing providential care of the Creator God leading up to the Exodus were incorporated into new narratives in the Wisdom of Solomon to remind the Jewish audience how God acts to save the just and the righteous (Murphy 2002:90-94). In a theologically creative manner, wisdom (as divine personification) and history (as memories of salvation during the Exodus) are combined in the Wisdom of Solomon to convince the Jews in the diaspora that justice will prevail - not only in this life but also thereafter. ${ }^{32}$ By means of poetic imagery, rhetorical skill, historical reinterpretation and imaginative wisdom theology, religious identity is not only bolstered to resist a dominant Greco-Roman culture but also to develop a positive view of creation according to the values of wisdom exemplified by the reinterpreted exodus traditions. ${ }^{33}$

\section{Acknowledgements}

The article is dedicated to Piet Venter, professor of Old Testament at the University of Pretoria, who has just retired after several decades of being committed to solid scholarship. Piet Venter made a significant contribution to Biblical Studies in South Africa by addressing areas of research often neglected by local scholars: the canon of the Hebrew Bible or Old Testament; the book of Daniel; Jewish Apocalyptic Literature and Deutero-canonical books like Enoch and Jubilees et cetera.

\section{Competing interests}

The author declares that he has no financial or personal relationship(s) which may have inappropriately influenced him in writing this article.

\section{References}

Barclay, J., 1996, Jews in the Mediterranean Diaspora from Alexander to Trajan (323 $B C E-117$ CE), Clark, Edinburgh

Blenkinsopp, J., 1981, 'Interpretation and the Tendency to Sectarianism: An Aspect of Second Temple History', in E.P. Sanders, A.I. Baumgarten \& A. Mendelson (eds.), Jewish and Christian Self-Definition. II Aspects of Judaism in the Graeco-Roman Period, pp. 1-26, SCM, London.

Cheon, S., 1997, The Exodus Story in the Wisdom of Solomon: A study in Biblical Interpretation, Sheffield Academic Press, Sheffield. (JSPS 23).

Clifford, R.J., 2002, 'The Exodus in the Christian Bible: The case for the "figural" reading', Theological Studies 63, 345-361.

Collins, J.J., 2000, 'The Afterlife in Apocalyptic Literature', in A.J. Avery-Peck \& J. Neusner (eds.), Judaism in Late Antiquity Part Four: Death, Life-after-death, resurrection and the World-to-come in the Judaisms of Antiquity, pp. 119-139, Brill, Leiden.

32.The author of the Wisdom of Solomon appealed to the history of Israel to illustrate the work of personified Wisdom through the impact of divine justice (Enns 2012:397)

33.There is some irony in the reception history of the Wisdom of Solomon that despite its initial Jewish audience it made little impact on later Jewish theological reflection (Wis 16:25-26 and b.Yoma 75a); whilst its impact on early Christian literature was quite extensive - Wisdom 13:1-9 and Romans 1:19-20; Wisdom literature was quite extensive - Wisdom $13: 1-9$ and Romans 1:19-20;
$14: 22-27$ and Romans 1:24, 26-31 et cetera (DeSilva 2002:149-152). 
Collins, J.J., 2005a, 'Anti-Semitism in Antiquity? The Case of Alexandria', in J.J. Collins (ed.) Jewish Cult and Hellenistic Culture: Essays on the Jewish Encounter with Hellenism and Roman Rule, pp. 181-201, Brill, Leiden. (JSJS 100).

Collins, J.J., 2005b, 'Hellenistic Judaism in recent Scholarship', in J.J. Collins (ed.), Jewish Cult and Hellenistic Culture: Essays on the Jewish Encounter with Hellenism and Roman Rule, pp. 1-20, Brill, Leiden. (JSJS 100).

Collins, J.J., 2005c, 'The Reinterpretation of Apocalyptic Traditions in the Wisdom of Solomon', in J.J. Collins (ed.), Jewish Cult and Hellenistic Culture: Essays on the Jewish Encounter with Hellenism and Roman Rule, pp. 143-158, Brill, Leiden. (JSJS 100).

Daube, D., 1963, The Exodus Pattern in the Bible, Faber \& Faber, London.

Dell, K., 2000, 'Get Wisdom, Get Insight': An Introduction to Israel's Wisdom Literature, Darton, Longman \& Todd, London.

DeSilva, D.A., 2002, Introducing the Apocrypha: Message, Context and Significance, Baker Academic, Grand Rapids.

Enns, P., 2008, 'Wisdom of Solomon', in T. Longman III \& P. Enns (eds.), Dictionary of the Old Testament: Wisdom, Poetry \& Writings, pp. 885-891, IVP Academic, Downer's Grove.

Enns, P., 2012, 'Pseudo-Solomon and his Scripture: Biblical Interpretation in the Wisdom of Solomon', in M. Henze (ed.), A Companion to Biblical Interpretation in Early Judaism, pp. 389-414, Eerdmans, Grand Rapids.

Focke, F., 1913, Die Entstehung der Weisheit Solomos, Vandenhoeck \& Ruprecht, Göttingen. (FRLANT 5).

Gilbert, M., 1984, 'Wisdom Literature', in M.E. Stone (ed.), Jewish Writings of the Second Temple Period, pp. 301-313, Aan Gorcum, Assen.

Goodrick, A.T.S., 1913, The Book of Wisdom, Rivingtons, London

Green, B., 2003, 'The Wisdom of Solomon and the Solomon of Wisdom: Tradition's transpositions and human transformation', Horizons 30, 41-66.

Gruen, E.S., 1998, Heritage and Hellenism: The Reinvention of Jewish Tradition University of California Press, Berkeley.

Horbury, W., 2000, 'The Wisdom of Solomon', in J. Barton \& J. Muddiman (eds.), The Oxford Bible Commentary, pp. 650-667, Oxford University Press, Oxford.

Kolarcik, M., 2009, 'Solomon, Wisdom of', in K.D. Sakenfeld (ed.), The New Interpreter's Dictionary of the Bible S-Z, vol. 5, pp. 330-334, Abingdon, Nashville. http://dx.doi. org/10.1163/ej.9789004186125.i-234.14

Kolarcik, M., 2010, 'Sapiential Values and Apocalyptic Imagery in the Wisdom of Solomon', in G.G. Xeravits \& J. Zsengeller (eds.), Studies in the Book of Wisdom, pp. 23-36, Brill, Leiden. (JSJS 142).

Larcher, C., 1969, 'L'immortalite de l'âme et les retributions transcendantes', in C. Larcher (ed.), Etudes sur le livre de la Sagesse, pp. 237-327, Gabalda, Paris.
Lietaert Peerbolte, B.J., 2006 'The hermeneutics of Exodus in the book of Wisdom', in R. Roukema (ed.), The Interpretation of Exodus: Studies in Honour of Cornelis Houtman, pp. 97-116, Peeters, Leuven.

Murphy, R., 2000, 'Death and Afterlife in the Wisdom Literature', in A.J. Avery-Peck \& J. Neusner (eds.), Judaism in Late Antiquity, Part Four: Death, Life-after-death, resurrection and the World-to-come in the Judaisms of Antiquity, pp. 101-116, Brill, Leiden.

Murphy, R.E., 2002, The Tree of Life: An Exploration of Biblical Wisdom Literature, Eerdmans, Grand Rapids.

Nickelsburg, G.W.E., 2000, 'Judgment, Life-after-Death and Resurrection in the Apocrypha and the Non-Apocalyptic Pseudepigrapha', in A.J. Avery-Peck \& J. Neusner (eds.), Judaism in Late Antiquity, Part Four: Death, Life-after-death, resurrection and the World-to-come in the Judaisms of Antiquity, pp. 141-162 Brill, Leiden.

Perdue, L.G., 2007, Wisdom Literature: A Theological History, Westminster John Knox Louisville.

Perdue, L.G., 2008, The Sword and the Stylus: An Introduction to Wisdom in the Age of Empires, Eerdmans, Grand Rapids.

Reese, J.M., 1965, 'Plan and Structure in the Book of Wisdom', Catholic Biblical Quarterly 27, 391-399.

Reese, J.M., 1970, Hellenistic Influence on the Book of Wisdom and Its Consequences, Biblical Institute Press, Rome.

Stone, M.E., 1980, Scripture, Sects and Visions, Fortress, Philadelphia.

Stuart, S.S., Jr, 1973, 'The Exodus Tradition in Late Jewish and Early Christian Literature: A General Survey of the Literature and a Particular Analysis of the Wisdom of Solomon, II Esdras and the Epistle to the Hebrews', unpublished PhD Dissertation, Department Biblical Studies, Vanderbilt University.

Von Rad, G., 1972, Wisdom in Israel, SCM, London.

Weeks, S., 2010, An Introduction to the Study of Wisdom Literature, T\&T Clark, London.

Wiles, J.K., 2002, 'Wisdom of Solomon', in W.E. Mills \& R.F. Wilson (eds.), Mercer Commentary on the Bible, vol. 5 'Deuterocanonicals/Apocrypha', pp. 35-50, Mercer University Press, Macon. http://dx.doi.org/10.1088/0963-6625/11/1/701

Winston, D., 1979, The Wisdom of Solomon, Doubleday, New York. (Anchor Bible Commentary).

Wright, A., 1967, 'The Structure of the Book of Wisdom', Biblica 48, 165-184.

Zsengeller, J., 2010, “'The Taste of Paradise" Interpretation of Exodus and Manna in the Book of Wisdom', in G.G. Xeravits \& J. Zsengeller (eds.), Studies in the Book of Wisdom, pp. 197-216, Brill, Leiden. (JSJS 142). http://dx.doi.org/10.1163/ ej. 9789004186125 . $\mathrm{i}-234.74$ 